\title{
Farmer's Satisfaction Regarding Land Consolidation in Turkey
}

\author{
Osman Karkacier ${ }^{1}$, Selma Karabaş ${ }^{2 *}$ \\ ${ }^{1}$ Department of Economics, Faculty of Economics and Administrative Sciences, Akdeniz University, 07058 Antalya, Turkey \\ E-mail: okarkacier@gmail.com,ORCID: https://orcid.org/0000-0003-0470-4374 \\ ${ }^{2 *}$ Department of Management, Faculty of Economics and Administrative Sciences, Karatekin University, 18100 Çankırl, Turkey \\ Corresponding author, E-mail: slmkrbs55@gmail.com,ORCID: https://orcid.org/0000-0002-4878-4735
}

\begin{tabular}{l|l}
\hline A R T I C L E I N F O & A B S T R A C T \\
\hline Research Article & $\begin{array}{l}\text { Farmland consolidation is defined as the aggregation of farm lands that are fragmented and } \\
\text { dispersed in agricultural sector with the aim of increasing their size for efficiency. The aim of } \\
\text { study is to determine the effects of land consolidation practice and its impact on farmer satisfaction } \\
\text { levels. Farmer satisfaction analysis was conducted on farmers which have land consolidation } \\
\text { practice areas in different regions in Turkey. The data was obtained to be conducted from 1349 } \\
\text { farmer interviews in } 10 \text { provinces by survey in 2015, and it was based on Likert scale that } \\
\text { measured farmer satisfaction level. The data which is used in this analysis was tested by reliability } \\
\text { analysis, and the results were obtained via factor analysis and logistic regression. It was found that } \\
\text { Accepted : 04/01/2019 } \\
\text { has positive opinion on land consolidation over } 87 \text { percent of farmers, and also was recommended } \\
\text { these practices to other farmers. Moreover, the results showed that the important ones from } \\
\text { effective factors on farmer satisfaction can be listed as follows: cost reduction, decreasing conflicts } \\
\text { between farmers, irrigation and drainage efficiencies, having confidence in technical staff, and } \\
\text { facilitating agricultural works. }\end{array}$ \\
$\begin{array}{l}\text { Keywords: } \\
\text { Fonsolidation } \\
\begin{array}{l}\text { Farmer } \\
\text { Satisfaction }\end{array} \\
\begin{array}{l}\text { Likert scale } \\
\text { Turkey }\end{array}\end{array}$
\end{tabular}

Turkey

This work is licensed under Creative Commons Attribution 4.0 International License

\section{Introduction}

Land consolidation may be described as the planned readjustment of the pattern of the ownership of land parcels with the aim of forming larger and more rational land holdings (Pasakamis and Mailiene, 2010). The relationship between land and the people is profound. People's standard of living, wealth, social status and aspirations are all closely linked to land (Nirula and Thapa, 2005).

Land consolidation projects (LCPs) are costly rural development actions that are often questioned. Integrated LCPs are geographically confined Land Rural Development Actions and their extant evaluation involves interdisciplinary research, in order to predict changes in farmers' behavior, patterns of land use and in crops and technologies used (Coelho et al., 2001).

Many Western European countries have a long tradition for land consolidation. In Denmark, the land consolidation program has roots more than two hundred years ago (Hartvigsen, 2005).) Land consolidation is a standard tool for ensuring rural development and for increasing land use effectiveness. It is also a very useful instrument for erosion control in rural landscapes (Mihara, 1996).
Analysis on land consolidation benefits is an important part of the study on the land consolidation theory and practice. It can improve land consolidation theory and guide land consolidation practice to an analysis on its on economic, environment and social development.

Though the aims and content of land consolidation are different in different countries, the practice showed that it could increase production and income, protect and improve the environment and provide farmers with fine living conditions. So the comprehensive benefits of land consolidation are the aggregation of economic, environmental, social and landscape benefits. The economic benefits of land consolidation are the effects of the practice upon the national economy and the farmers of land consolidation areas. The environmental benefits of land consolidation are the effect of the practice upon the structure and function of natural ecosystem and the environment. The social benefits of land consolidation are the effect of the practice upon the rural environment, and social economy, as well as the reasonable use of natural resources. The landscape benefits of land consolidation are the effects of the practice upon the rural landscape (Zhengfeng and Baiming, 2003). 
In many countries, including the EU countries, intensive agriculture has resulted in serious problems such as pollution of soil, water and air, and a decrease in the number of wild animals and plants. Today land consolidation is an effective instrument in rural development, which includes improvements to agricultural production, employment, taxation policy, infrastructure, public facilities, housing and the protection of natural resources.

Revealing the land consolidation application results from a technical perspective is possible. To achieve desired outcomes of land consolidation, a radical change is necessary in the structure of agricultural management. The satisfaction of the farmers has a critical importance and should be taken into account; while making this radical change in constitutional texture of agricultural management. Agriculture is not only an economic sector but also a lifestyle and an environment where family life is carried on. For these reasons, a change in agricultural management structure has to please people who work in this sector. A farmer who is happy and prosperous will be open-minded to the innovations so will be more productive. Satisfaction levels of farmers have been observed with a focus in land consolidation applications and farmers' satisfaction analysis.

Various analyses exist in that aim at literature finding out the satisfaction levels of people. Methods in studies based on customer satisfaction principals have been applied to this research. Satisfaction, attitudes and tendencies of the farmers on each stage have been measured with Likert scale questions.

Land consolidation applications and field inner side improvement works have been analysed separately before and after application. Explanatory variable of this research model is the satisfaction level of farmers regarding land consolidation applications. Eight factors have been formed to explain this explanatory variable. Under these 8 factors, 35 questions have been formed, by this way measure has been obtained.

Factors that are obtained via results of exploratory factor analysis, have been tested via regression analysis so that; hypothesis that is set up has been taken into decision. Hypothesis had been written as: satisfaction of farmers regarding land consolidation applications effects $\mathrm{X}$ factor positively. Therefore, effects of eight factors and the items regarding land consolidation have been determined. So that; the most important factor affecting the farmer is determined. For this reason, an opportunity has arisen to derive connection between expected success from land consolidation and components which became prominent via this study.

The total consolidated land area in Turkey is 2.9 million ha approximately. The 2.4 million ha of the total area have been completed thanks to the studies carried out between the years 2003-2014 by General Directorate of Agricultural Reform. Currently, additional land consolidation studies in 1.98 million ha have still been going on.

In this rapid land consolidation process, searching satisfaction level of farmers and generalizing its results are very crucial. In this study, it has been observed that farmers have great attention to land consolidation and $87.1 \%$ of the farmers have thought that land consolidation is beneficial.

\section{Materials and Methods}

Field research focusing on land consolidation and farmer satisfaction analysis had been carried out in this study. Face to face questionnaires should be conducted in order to get the proper data in these kinds of researches. Statistical sampling methods had been used not only to determine the number of farmers that will participate in the questionnaire but also to determine the villages and provinces where the questionnaires would be conducted. The study had been conducted in 10 provinces which are thought to be representing agricultural regions according to field sampling. Afterwards, 1349 questionnaires had been carried out in selected districts and villages with determined farmers in 2015 (Ministry of Food, Agriculture and Husbandry of Turkey, 2015).

In this context, questions had been asked to reveal the viewpoints and tendencies of farmers. In other words, Likert scaled questions had been used to determine to what extent farmers agree or disagree with the statements. In these statements, five scaled Likert is used to determine the satisfaction level from "extremely satisfied" to "extremely dissatisfied" (Tezbaşaran, 1997).

Data analysis methods used in the study had been sorted from conventional methods to improved statistical methods that are mentioned below: (Serper, 2010).

- Descriptive statistical methods

- Factor analysis

- Logistic regression analysis

Eight hypotheses directed to the target group of the research have been built as follows:

$\mathrm{H}_{1}$ :Decrease in the general costs via land consolidation affects farmers' satisfaction positively

$\mathrm{H}_{2}$ :Increased efficiency in irrigation via land consolidation affects farmers' satisfaction positively

$\mathrm{H}_{3}$ :Convenience in general agricultural work via land consolidation affects farmers' satisfaction positively

$\mathrm{H}_{4}$ :Success in general parcelling via land consolidation affects farmers' satisfaction positively

$\mathrm{H}_{5}$ :The confidence to the technical personnel carrying out land consolidation affects farmers' satisfaction positively

$\mathrm{H}_{6}$ :The drainage system which works effectively in land consolidation affects farmers' satisfaction positively

$\mathrm{H}_{7}$ :The improvement in transportation between parcels and highways via land consolidation affects farmers' satisfaction positively

$\mathrm{H}_{8}$ :Decrease in the dispute between farmers via land consolidation affects farmers' satisfaction positively.

\section{Results and Discussions}

The data was obtained to be conducted from 1349 farmer interviews". The information about the research findings is as follows.

Summary of The Results of Descriptive Statistical Methods

The aim of this study is to make certain and accurate decisions about satisfaction levels of farmers by using mods and arithmetic means obtained from central distribution from each descriptive statistics. Summarized decisions regarding to detailed assessment can be seen in Table 1. 
The mode value is the most repeated value in the series. The reason for the efficiency of the mode value in the table is that it does not make the wrong decision by simply relying on the arithmetic mean.

\section{Summary of The Results of Factor Analysis}

The prior condition of the Factor Analysis is to carry out sample qualification tests which are known as KMO (Kaiser-Meyer-Oklin) and Bartlett Tests. For the farmer satisfaction in land consolidation analysis evaluation compliance scale for KMO sample test is 0.75 and ChiSquare value for Bartlett test is 32016.154 and found meaningful at $1 \%$. According to these values (Table 2). The scale is used in this research is found to be convenient with the factor analysis. On the other hand, Cronbach's Alpha coefficients used in the confidence test for factor analysis vary between the values 0.772 and 0.880 for all sub factors. It is found that Cronbach's Alpha coefficient vary between 0.799 and 0.933 for Factor Analysis, and for the whole questionnaires, it is found as 0.896 . Since related coefficient values are high, the questionnaire and factor analysis of the data are found convenient statistically.

The status of analysis calculated by rotated factors and the scale consisting of 33 articles and 8 factors can be seen in Table 2.
New dimensions and factors are summarized in Table 3 with using rotated factor load and taking into account the meanings of the factors. This scale is constituted using factor analysis by researchers and introduced to the literature. Scale is consisting of 6 factors and 33 articles.

\section{The Results of Regression Analysis}

In the study, the dependent variable of satisfaction level of farmers regarding land consolidation have been measured by the question "Do you recommend land consolidation to other farmers? The answers to this question are limited as "yes" or "no". The indecisive ones have not been accepted as "yes". The answers have been categorized as $0=$ no, $1=$ yes. Since dependent variable is dummy variable, binary logit regression model has been preferred. Regression analysis has been carried out by determined factors that are obtained from factor analysis. With reference to the scale formed by factor analysis, 8 factors are found to be meaningful. These 8 factors have been put into the right side of the model as independent variable in the factor regression model. So that, in what ways and how the factors have affected the satisfaction level have become evident.

Table 1 Total results of descriptive analysis and decision (from central distribution units)

\begin{tabular}{|c|c|c|c|}
\hline Dimension / sub dimension (Question Statement) & Arithmetic Mean & Mod & Decision* \\
\hline \multicolumn{4}{|l|}{ General Dimension } \\
\hline Individual satisfaction in land consolidation & 3.55 & 5 & Strong satisfaction \\
\hline Preliminary briefing & 3.44 & 4 & Satisfaction \\
\hline Interest of the personnel & 3.08 & 2 & Weak satisfaction \\
\hline Meeting the expectation & 2.97 & 5 & Satisfaction \\
\hline Obligatory enforcement & 3.71 & 5 & Strong satisfaction \\
\hline \multicolumn{4}{|l|}{ Extents of Disputes } \\
\hline Border disputes & 4.34 & 5 & Strong satisfaction \\
\hline Road disputes & 4.63 & 5 & Strong satisfaction \\
\hline Proper water sharing & 4.06 & 5 & Strong satisfaction \\
\hline \multicolumn{4}{|l|}{ Efficient Parcelling } \\
\hline The distance of irrigation channels to parcels & 3.35 & 5 & Strong satisfaction \\
\hline The shape of parcels & 4.12 & 5 & Strong satisfaction \\
\hline The distance of parcels to way & 4.37 & 5 & Strong satisfaction \\
\hline The size of parcels & 4.08 & 5 & Strong satisfaction \\
\hline The decrease in number of parcels & 4.04 & 5 & Strong satisfaction \\
\hline \multicolumn{4}{|l|}{ Facilitation in Agricultural Activities } \\
\hline Facilitation in ploughing & 4.71 & 5 & Strong satisfaction \\
\hline Facilitation in harvesting & 4.69 & 5 & Strong satisfaction \\
\hline Increase in fertility & 3.93 & 5 & Strong satisfaction \\
\hline \multicolumn{4}{|l|}{ Cost } \\
\hline Decrease in workforce cost & 4.35 & 5 & Strong satisfaction \\
\hline Decrease in diesel fuel cost & 4.34 & 5 & Strong satisfaction \\
\hline Less frazzling in tractors and its equipment & 4.47 & 5 & Strong satisfaction \\
\hline Providing time saving & 4.39 & 5 & Strong satisfaction \\
\hline \multicolumn{4}{|l|}{ Irrigation - Levelling - Drainage Efficiency } \\
\hline Easiness in water taking to the parcel & 3.25 & 5 & Strong satisfaction \\
\hline The closeness of parcel to electricity & 3.43 & 5 & Strong satisfaction \\
\hline Convenience of leveling & 2.35 & 1 & Strong complaint \\
\hline Water quantity and sufficiency & 3.21 & 5 & Weak satisfaction \\
\hline Water loss in channels & 3.80 & 5 & Satisfaction \\
\hline Sufficiency of drainage channels & 3.07 & & Strong satisfaction \\
\hline Clogging of drainage channels & 2.92 & 1 & Strong dispute \\
\hline
\end{tabular}


Table 2 Rotated factor loads

\begin{tabular}{|c|c|c|c|c|c|c|c|c|}
\hline Sub Factors & 1 & 2 & 3 & 4 & 5 & 6 & 7 & 8 \\
\hline Decrease in Labour Cost & 0.899 & & & & & & & \\
\hline Decrease in fuel diesel cost & 0.898 & & & & & & & \\
\hline Less frazzling in tractor and equipment & 0.878 & & & & & & & \\
\hline Easiness in tractor and equipment use & 0.870 & & & & & & & \\
\hline Time saving in works & 0.853 & & & & & & & \\
\hline Decrease in costs in general & 0.802 & & & & & & & \\
\hline Increase in land fertility & 0.520 & & & & & & & \\
\hline Easiness in water taking into parcel & & 0.805 & & & & & & \\
\hline $\begin{array}{l}\text { The closeness of parcel to electricity which is } \\
\text { used in water taking into parcel }\end{array}$ & & 0.775 & & & & & & \\
\hline $\begin{array}{l}\text { Min water loss while building irrigation } \\
\text { channels }\end{array}$ & & 0.765 & & & & & & \\
\hline Closeness of tertiary channels to the parcel & & 0.715 & & & & & & \\
\hline Effectiveness of water distribution and quantity & & 0.696 & & & & & & \\
\hline The distance of irrigation channels to parcel & & 0.625 & & & & & & \\
\hline Convenience of land leveling to irrigation & & 0.529 & & & & & & \\
\hline Easiness in ploughing & & & 0.872 & & & & & \\
\hline Easiness in harvesting & & & 0.860 & & & & & \\
\hline Easiness in sowing and planting & & & 0.859 & & & & & \\
\hline Easiness in agricultural works & & & 0.698 & & & & & \\
\hline Decrease in disputes for roads & & & 0.543 & & & & & \\
\hline Increase in size of parcel & & & & 0.732 & & & & \\
\hline Shape of parcel & & & & 0.725 & & & & \\
\hline Decrease in parcel after consolidation & & & & 0.717 & & & & \\
\hline Improvement in width and length of parcel & & & & 0.694 & & & & \\
\hline Increase in parcel size after consolidation & & & & 0.623 & & & & \\
\hline Interest of technical personnel & & & & & 0.763 & & & \\
\hline $\begin{array}{l}\text { Consideration of farmer demands during } \\
\text { interviews }\end{array}$ & & & & & 0.758 & & & \\
\hline Confidence to technical personnel & & & & & 0.719 & & & \\
\hline Good working of drainage channels & & & & & & 0.845 & & \\
\hline Proper localization of drainage channels & & & & & & 0.827 & & \\
\hline Harmony of parcels and ways & & & & & & & 0.847 & \\
\hline Transportation from houses to parcels & & & & & & & 0.774 & \\
\hline Decrease in water use dispute & & & & & & & & 0.639 \\
\hline Decrease in border disputes & & & & & & & & 0.613 \\
\hline
\end{tabular}

While deciding the convenient model in regression analysis, various criteria have been utilized. In farmer satisfaction on land consolidation analysis;

$\begin{array}{ll}\text { Satisfied mode } & : 0 \text { (zero) } \\ \text { Dissatisfied mode } & : 1 \text { (one) }\end{array}$

For the goodness of fit in logistic regression analysis, these transactions are carried out: Evaluations are carried out taking into effect certain variables or not and their contribution to the explanation power. For this reason, G statistics have been used for test purpose. Comparing observed values with estimated values depend on function which is "log possible (log likelihood-LL)". Good model is the model that constitutes high probability of observed values. In other words, this means that $-2 \mathrm{LL}$ is smaller (Akgün, 2007; Karabaş, 2013).

The hypotheses which are constituted regarding to $\mathrm{G}$ statistics,

$$
\begin{aligned}
& \mathrm{H}_{0}: \beta_{0}=\beta_{1}=\beta_{2}=\ldots \ldots \ldots \ldots \ldots \ldots . \mathrm{B}_{\mathrm{k}}=0 \\
& \mathrm{H}_{1}: \beta_{0} \neq \beta_{1} \neq \beta_{2} \neq \ldots \ldots \ldots \ldots \ldots \ldots \mathrm{B}_{\mathrm{k}} \neq 0
\end{aligned}
$$

G statistics;

$\mathrm{G}=\mathrm{D}$ (only truncation model) $-\mathrm{D}$ (model which consisting the variables)

$$
\mathrm{G}=765.637-447.557=318.08
$$

In the model, starting value of"-2 Log Likelihood" is 765.637. The goodness of fit statistic is -2 and its Log Likelihood value is 447.557 for Step 1 model including the constant and other variables. G statistics is Chi-square value which is 318.08 . This value is achieved via taking the difference of the starting value of "-2 Log Likelihood" which is 765.637 and Log Likelihood value which is 447.557. This value is found significant at 0.000 . While excluding Chi-square statistics constant. $\mathrm{The}_{0} \mathrm{H}_{0}$ that all the independent variables which are zero rejected. This test is equal to the F statistics in the regression model (Gürsakal, 2012).

For this reason, it can be said that independent variables in the model are significant at 0.000 . There is another goodness of fit test called Hosmer-Lemeshow Test. (Gujarati, 2005). According to this test, the model is found significant. Following the significance of model 
statistically, each variable is searched for significance and commented.

Regression analysis results are given in Table 3. Cost factor is the variable of measuring satisfaction on consolidation as a result of agricultural cost change. It is known that with the parcel efficiency, less wear in tractor and equipment, decrease in fuel diesel, time saving in works and decrease in labor force and decrease in costs are possible in general. In descriptive analysis result part, satisfaction level and the evaluation of farmers on cost advantages have been assessed and strong satisfaction is observed. With the regression analysis, results have been tested and decisions have been taken on hypothesis. The coefficient of cost factor is 0.872 and positive. It can be seen that coefficient is significant (Table 3 ). This positive coefficient shows that cost satisfaction effects consolidation participation positively. In addition to these, Odds ratio reveals how much the positive effect is. The odds ratio of cost factor is 2.391 which mean that one point increase in cost increases consolidation participation ratio 2.391 .

Table 3 Regression analysis result summary table (binary logit model)

\begin{tabular}{ll|cccc}
\hline & Factors & B Coefficient & SE Std. Error & P* Significant Level & Odd Ratio** (Exp B) \\
\hline FAC1_1 & Cost & 0.872 & 0.125 & $0.000^{\mathrm{a}}$ & 2.391 \\
FAC2_1 & Irrigation & 0.287 & 0.146 & $0.050^{\mathrm{b}}$ & 1.333 \\
FAC3_1 & Easiness & 0.516 & 0.107 & $0.000^{\mathrm{a}}$ & 1.676 \\
FAC4_1 & Parcel Efficiency & 0.888 & 0.127 & $0.000^{\mathrm{a}}$ & 2.429 \\
FAC5_1 & Trust & 1.494 & 0.181 & $0.000^{\mathrm{a}}$ & 4.454 \\
FAC6_1 & Drainage & -1.149 & 0.182 & $0.000^{\mathrm{a}}$ & 0.317 \\
FAC7_1 & Way & 0.086 & 0.158 & $0.587^{\mathrm{c}}$ & Not meaningful \\
FAC8_1 & Dispute & 0.120 & 0.123 & $0.329^{\mathrm{c}}$ & Not meaningful \\
\hline \multicolumn{2}{l}{ Constant Term } & 3.532 & 0.259 & 0.000 & Not meaningful \\
\hline
\end{tabular}

${ }^{*} \mathrm{a}$; $\alpha=$ As per 0,01 it is significant, b; as per $\alpha=0,05$ it is significant, c; It is significant at the desired level, **It is the increase ratio in the dependent variable based on the change with the same direction in factors

The second factor of the model is irrigation. In land consolidation; irrigation quantity water distribution and efficiency of the channels affect satisfaction. It has been observed that farmers express their opinions mostly in field studies. The irrigation factor coefficient is 0.287 . It is positive and found significant. Odds ratio is 1.333 and satisfaction from irrigation increase consolidation by 1.33 times. As per descriptive analysis results, low level of complaints on irrigation quantity and distribution are seen, while strong satisfaction on parcelling and efficiency on irrigation channels are observed. In odds ratio, a coefficient parallel to this has been obtained.

Easiness in agricultural works is one of the advantages of consolidation. Easier movement of truck, harvest and plough operations are one of the properties gained from consolidation. Easiness on agricultural work is named as easiness and it has been calculated as 0.516 and both positive and significant. As per odds ratio easiness increases consolidation recommendation by 1.676 times. As for the satisfaction level taken in descriptive analysis part satisfaction level parallel to this level has been obtained.

The main target of the land consolidation is to gather small and dispersed parcels. In line with this parcel efficiency as per regression analysis is found positive and significant. Its odd ratio is 2.429 and ranks number 2 as per regression analysis results (Table 3 ). Such a strong result on this in descriptive results strengthen these results. As a result, successful results on projects come across satisfaction on farmers.

Especially, the evaluation of technical team on projects successfully exhibits positive effect on farmers. The closeness of technical personnel to the farmers' confidence paying attention to the farmers' demands have importance in gaining success. By taking these into account, impression and satisfaction on farmers made by project engineers have been searched. Factor scores based on "Do you count on technical personnel?" and "Have your demands taken into consideration" questions have been considered as independent variable. Therefore it is possible to substitute social variable in the technical application. The coefficient of the trust factor obtained from binary logit is 1.494 it is positive and significant. The odds ratio is 4.454 and this is the highest ratio calculated. This means that trust ranks in priority in land consolidation which affects results directly. That the odd ratio is high is the first and foremost factor that effects consolidation more than 4 times (Table 3).

In case of ground water in field works in land consolidation, drainage takes place in the projects. In terms of drainage efficiency, drainage performs well and its location in preventing interruption in the field work is of importance. It has been observed that farmers complain where there is drainage. In descriptive analysis results, there are strong complaints about the blockage on the drainage channels. It is also seen that findings parallel to these results have been calculated in regression analysis. The drainage factor is -1.149 and found significant (Table 3 ). As per the result, it can be commented that drainage efficiency factor affects farmer satisfaction negatively. As a conclusion, the mistakes made in drainage works induce farmers' dissatisfaction. The adjusted odds ratio of this factor is 3.154 which mean that efficiency of drainage is more than 3 times negatively. Way and dispute in binary logit regression analysis result table are not found significant at the desired levels. Therefore, it is not possible to comment on regression result of these factors. However, descriptive analysis results of the variables under these factors can be commented. When looked into factor loads in the factor analysis, this item and factors are important in satisfaction analysis. Especially, disputes on borders, ways and water usage between farmers have been omitted 
through consolidation have been observed and testified descriptively. That these factors are insignificant in the regression analysis does not mean that these factors affect negatively nor affect satisfaction negatively.

\section{Conclusion}

The results of study showed that the important ones from effective factors on farmer satisfaction can be listed as follows: cost reduction, decreasing conflicts between farmers, irrigation and drainage efficiencies, having confidence in technical staff, and facilitating agricultural works. The data was obtained from 1349 farmers which to conduct farmer satisfaction analysis. The data is analysed via factor analysis and logistic regression. It was found that has positive opinion on land consolidation over 87 percent of farmers, and also was recommended these practices to other farmers.

A study which analysed socio-economic factors affecting farmer decisions on land consolidation. It was determined that the level of the farmers adopting land consolidation is generally moderate. However, the slow pace of land consolidation investments has a negative impact on farmers ' view related to consolidation (Aktaş et all., 2006). The other study declared that thanks to land consolidation occur reduction in the number of parcels per enterprises, increasing in average enterprise size, reduction in the processing time required for processing the land, reduction in the preparation time, reduction in time en route and total working time (Boztoprak et al., 2015).

In line with the hypothesis, following decisions are derived:

- Cost factor is positive and significant. Odds ratio is 2.39 which means that 1 unit of decrease in costs affects satisfaction 2.39 times positively.

$\mathrm{H}_{\text {Cost } 0}$ : Cost reduction via land consolidation does not affect farmer satisfaction positively

$\mathrm{H}_{\text {Cost } 1}$ : Cost reduction via land consolidation affects farmer satisfaction positively

According to this, $\mathrm{H}_{\text {Cost } 0}$ is rejected and $\mathrm{H}_{\text {Cost1 }}$ is accepted.

- Irrigation factor is positive and significant. As per odds ratio, success in application increase satisfaction by 1.33 .

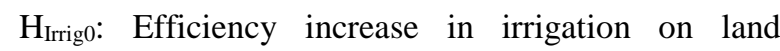
consolidation does not affect farmers' satisfaction positively

$\mathrm{H}_{\text {Irrig1: }}$ Efficiency increase in irrigation on land consolidation affects farmers' satisfaction positively

According to this, $\mathrm{H}_{\text {Irrig0 }}$ is rejected and $\mathrm{H}_{\text {Irrig1 }}$ is accepted.

- The coefficient of the easiness factor for agricultural operations is positive and significant. Odds ratio is 1.67 and easiness in operation affect satisfaction by 1.67.

$\mathrm{H}_{\text {Eas0 }}$ : Easiness in agricultural works via agricultural consolidation does not affect farmer satisfaction positively.
$\mathrm{H}_{\text {Eas 1: }}$ Easiness in agricultural works via agricultural consolidation affects farmer satisfaction positively.

According to this, $\mathrm{H}_{\text {Eas0 }}$ is rejected and $\mathrm{H}_{\text {Eas1 }}$ is accepted.

- $\quad$ PRS is the coefficient of the parcel efficiency which is positive and significant. Since odds ratio is 2.42 when there is a success in the parcelling, satisfaction increase by 2.42 times.

$\mathrm{H}_{\text {Prs } 0}$ : Land consolidation and success in general parcel allocation does not affect farmers' satisfaction positively

$\mathrm{H}_{\text {Prs1 }}$ : Land consolidation and success in general parcel allocation affect farmers' satisfaction positively According to this, $\mathrm{H}_{\mathrm{Prs} 0}$ is rejected and $\mathrm{H}_{\mathrm{Prs} 1}$ is accepted.

- Trust is the coefficient for the confidence to the technical personnel which is found positive and significant. As per odds ratio, when farmers rely on the personnel, satisfaction increases by 4.54 times. Since odds ratio is higher than others, it means that technical personnel play an important role in farmers' satisfaction.

$\mathrm{H}_{\mathrm{TRS} 0}$ : The confidence to the technical personnel carrying out land consolidation does not affect farmers' satisfaction positively

$\mathrm{H}_{\text {TRS1}}$ : The confidence to the technical personnel carrying out land consolidation affect farmers' satisfaction positively

According to this, $\mathrm{H}_{\text {TRS0 }}$ is rejected and $\mathrm{H}_{\mathrm{TRS} 1}$ is accepted.

- Drainage is one the issues that farmers mostly complain about in consolidation. As per findings where there is drainage, drainage factor coefficient is found negative in the regression analysis. According to this, there is dissatisfaction on drainage. In line with adjusted odds ratio, while there is an increase negativeness on drainage, dissatisfaction increases by 3.15 times. At this time, it is important to evaluate the hypothesis reverse;

$\mathrm{H}_{\text {DRN0 }}$ : The effective drainage system in land consolidation does not affect farmers' satisfaction positively

$\mathrm{H}_{\mathrm{DRN} 1}$ : The effective drainage system in land consolidation effects farmers' satisfaction positively

According to this, reject $\mathrm{H}_{\mathrm{DRN} 0}$ and accept $\mathrm{H}_{\mathrm{DRN} 1}$

Way and disputes are found significant in the regression analysis. Therefore, it is not possible to comment. However, it is possible to comment as per descriptive analysis results. As per factor loads, it can be understood that it is an important factor. In consolidation, farmers attach importance to the improvement on the ways and point out that resolving disputes play an important role in consolidation. What it has to do to increase satisfaction is provided confidence to land consolidation officers.

\section{References}

Akgün A, Çevik O. 2007. İstatistiksel Analiz Teknikleri. Emek Ofset Basımevi, İstanbul. 
Aktaş E, Bilgili ME, Akbay AÖ, Bal T. 2006. “Adana İli Karataş İlçesi Yemişli Köyünde Arazi Toplulaştırması Kararını Etkileyen Sosyo-Ekonomik Faktörlerin Belirlenmesi." https://www.researchgate.net/.../23543910

Boztoprak T, Demir O, Çoruhlu YE, Nişancı R. 2015. “Arazi Toplulaştırmasının Tarımsal İşletmelere Etkilerinin Araştırılması.” S.Ü. Müh. Bilim ve Tekn. Derg., c.3, s.3, 2015. ISSN: 2147-9364.

Coelho JC, Pinto PA, Silva MA. 2001. "Systems approach for the estimation of the effects of land Consolidation Project (LCPs): a model and its Applications.” Agricultural Systems, 68(3): 179-195.

Gujarati N. 2005. Temel Ekonometri. LiteratürYayınları, İstanbul.

Gürsakal N. 2012. Betimsel İstatistik. Dora Yayınları 6. Bask1, Bursa.

Hartvigsen M. 2005. Land Consolidation Pilot Projects in Europe. International Land Consolidation Conference, December 1-2, Budapest, Hungary.

Karabaş S. 2013. "Tüketicilerin İthal Hayvansal Ürünler Karşısındaki Tutum ve Davranışların Logistik Regresyon Analizi İle Tahmini." KMÜ Sosyal ve Ekonomik Araştırmalar Dergisi, 15 (24): 59-64.
Mihara M. 1996. "Effect of Land Consolidation on Erosion Processes in Semi-mountanious Paddy Fields of Japon." Journal of Agricultural Engineering Research, 64(3):237247.

Ministry of Food Agriculture and Husbandry 2015. General Directorate of Agricultural Reforms.

Nirula GS, Thapa GB. 2005. "Impacts and Causes of Land Fragmentation, and Lessons Learned from Land Consolidation in South Asia." Land Use Policy, 22(4):358372.

Pasakamis G, Mailiene V. 2010. "Towards Sustainable Rural Development in Central and Eastern Europe: Applying Land Consolidation." Land Use Policy, 27(2):545-549.

Serper Ö. 2010. Uygulamalı İstatistik 2. EzgiYayınları, Bursa.

Tezbaşaran A. 1997. Likert Tipi Ölçek Geliştirme Kılavuzu. İkinci Baskı. Türk Psikologlar Derneği Yayını, Ankara.

Zhenfeng Z, Baiming C. 2003. "Primary analysis on Land Consolidation Benefits." Transactions of CSAE, 19(2): 210213. 